\title{
Sphingolipids in the DNA Damage Response
}

\author{
Brittany Carroll ${ }^{2,3}$, Cat Donaldson ${ }^{2,3}$, and Lina Obeid ${ }^{1,2,3,{ }^{*}}$ \\ ${ }^{1}$ Northport VA Medical Center, Northport, NY 11768 \\ 2Department of Medicine, Stony Brook University, Stony Brook, NY 11794 \\ ${ }^{3}$ Stony Brook Cancer Center, Stony Brook University, Stony Brook, NY 11794
}

\begin{abstract}
Recently, sphingolipid metabolizing enzymes have emerged as important targets of many chemotherapeutics and DNA damaging agents and therefore play significant roles in mediating the physiological response of the cell to DNA damage. In this review we will highlight points of connection between the DNA damage response (DDR) and sphingolipid metabolism; specifically how certain sphingolipid enzymes are regulated in response to DNA damage and how the bioactive lipids produced by these enzymes affect cell fate.
\end{abstract}

\section{Introduction}

It is becoming increasingly evident in the literature that sphingolipid metabolizing enzymes are important targets of many chemotherapeutics and DNA damaging agents and therefore play significant roles in mediating the physiological response of the cell to DNA damage. Sphingolipid metabolites, including ceramide, sphingosine, and sphingosine 1-phosphate (S1P), are established bioactive lipids that play essential roles in cell growth, survival, and death (Mathias, Pena et al. 1998, Hannun, Luberto et al. 2001). It is well established that many cancer treatments often result in the generation of ceramide, which has been implicated in mediating the cell death response (Reynolds, Maurer et al. 2004); conversely a common survival strategy employed by cancer cells is the generation of the prosurvival lipid S1P formed by phosphorylating sphingosine, the product of ceramide hydrolysis (Gault and Obeid 2011). As the sphingolipid metabolites mentioned above can elicit both prosurvival and proapoptotic effects within the cell in response to DNA damage depending on which metabolite is formed, the regulation of the enzymes that produce these bioactive lipids is of great importance to cell fate and is the focus of this review. Here, we provide background about DNA damage response (DDR) and sphingolipid metabolism and discuss the currently known points of connection between the two, along with the therapeutic potential of targeting certain key sphingolipid metabolizing enzymes.

*Corresponding author. Lina.Obeid@ stonybrookmedicine.edu.

Publisher's Disclaimer: This is a PDF file of an unedited manuscript that has been accepted for publication. As a service to our customers we are providing this early version of the manuscript. The manuscript will undergo copyediting, typesetting, and review of the resulting proof before it is published in its final citable form. Please note that during the production process errors may be discovered which could affect the content, and all legal disclaimers that apply to the journal pertain. 


\section{A. Overview of Sphingolipid Enzymes and Metabolism}

As major constituents of cellular membranes, sphingolipids (SLs) were once thought to play merely structural roles within the cell, but are now well characterized as being bioactive signaling molecules that are important mediators of numerous biological processes including cell growth and survival as well as cellular senescence and death (Hannun and Obeid 2008). Ceramide (Cer), is considered the "hub" of SL metabolism and can be generated via three different pathways. De novo synthesis of Cer begins with condensation of serine and palmitoyl-CoA catalyzed by the enzyme serine palmitoyl transferase, forming 3-ketodihydorsphingosine. Following subsequent reduction and acylation reactions, dihydroceramide is produced and undergoes a final desaturation reaction catalyzed by dihydroceramide desaturase to form Cer. Cer can also be generated as a result of the catabolism of more complex SLs such as sphingomyelin (SM), through the action of a family of enzymes termed the sphingomyelinases (SMase). This group of enzymes catalyzes the hydrolysis of the phosphocholine headgroup of sphingomyelin to form Cer and free phosphocholine. Lastly, Cer can be generated via the salvage pathway where a family of enzymes known as the ceramide synthases (CerS) catalyze the N-acylation of fatty acids of differing chains lengths at the $\mathrm{C} 2$ position of the 18-carbon amino alcohol sphingosine (Sph) resulting in the formation of Cer. Once generated Cer can undergo further catabolism to produce Sph by a group of enzymes, the ceramidases (CDases). Following the generation of Sph, phosphorylation of this molecule by the sphingosine kinases (SKs) can occur to produce sphingosine-1-phosphate (S1P) (Hannun and Obeid 2008). The Sphingolipid metabolic network is a complex and interconnected set of reactions that generates abundant bioactive molecules therefore the regulation of the enzymes in this complex signaling pathway must be tightly regulated.

\section{B. Overview of DNA Damage Response}

The cellular DNA damage response (DDR) is elicited in response to UV radiation, ionizing radiation, chemotherapeutic agents, amongst other genomic injuries to the cell. The DDR is a complex network of interlinked signaling pathways, which results in apoptosis, cell cycle arrest and DNA repair. A basic overview of the key mediators of the DDR is discussed here in this introduction. The fundamental purpose of the DDR is to maintain genomic integrity of a cell or organism and, if compromised, would lead to a multitude of severe pathologies.

The cell possesses molecular sensors, such as the trimeric complex of Mre11, Nbs1 and Rad50, which directly detect damage sites in DNA. These signal to ATM (ataxiatelangiectasia mutated protein) and ATR (ATM and Rad3-related protein), which are the key transducers to the individual downstream DDR pathways (Czornak, Chughtai et al. 2008). p53 is a well-known tumor suppressor protein, being mutated in a large proportion of cancers (Kastan, Onyekwere et al. 1991). It is activated by ATM and/or ATR and acts as a critical effector in the DDR, playing roles in both the apoptotic and cell cycle arrest branches of the response. Also directly downstream from ATM and ATR are CHK1 and CHK2 - checkpoint kinases with the capability of eliciting multiple responses in the DDR (Chen and Poon 2008). CHK1 and CHK2 are able to feed into the p53-dependent pathways through p53 activation, hence stimulating apoptosis and cell cycle arrest in this way (Goto, Izawa et al. 2012). Independent of p53, checkpoint kinases are known to activate DNA 
repair processes through activation of BRCA2, which can also be activated directly by ATM and ATR (Dasika, Lin et al. 1999). They also cause cell cycle arrest through inhibition of cdc25, which would normally activate CDKs to drive the cell through the S-phase of the cell cycle (Goto, Izawa et al. 2012). p53-dependent cell cycle arrest is mediated by CDK inhibitors, such as p21 (Bunz, Dutriaux et al. 1998). Lack of CDK activity results in hypophosphorylation of $\mathrm{Rb}$ (retinoblastoma protein), which prevents the cell from progressing through its critical cycle checkpoints(Kaye 2002). p53 also drives an apoptotic pathway in the DDR, through BAX-mediated activation of caspase-3 (Polyak, Xia et al. 1997, Yin, Knudson et al. 1997). Once activated, caspase-3 is able to cleave PARP (polyADP ribose polymerase), a characteristic marker of cell apoptosis. BAX is subject to negative regulation through bcl-2 and positive feedback through caspase-2-mediated activation of BID (Upton, Austgen et al. 2008).

\section{Regulation of Sphingolipid Enzymes by DNA Damage}

\section{A. The Generation of Ceramide}

There are two major sources of ceramide generation: sphingomyelin hydrolysis by sphingomyelinases, and de novo ceramide synthesis by ceramide synthases. The following section addresses the families of enzymes responsible for these ceramide-generating processes, and how they relate to the cellular DNA damage response.

Sphingomyelinases-The sphingomyelinases (SMases) are a family of phosphodiesterases that catalyze the hydrolysis of sphingomyelin to ceramide and phosphorylcholine. The SMases are classified into three groups dependent on their optimum $\mathrm{pH}$ for activity: neutral sphingomyelinases (nSMases), acid sphingomyelinases (ASMases) and alkaline sphingomyelinases (alk-SMases). Each SMase occupies a distinct niche in terms of cellular localization and physiological function.

Neutral sphingomyelinase: Neutral SMases are so-called because they exhibit a neutral optimum $\mathrm{pH}$. There are currently four identified human nSMases: nSMase 1, nSMase 2, nSMase3, and MA-nSMase (mitochondrial associated-nSMase), encoded by genes SMPD25 respectively. nSMase 2 is by far the best characterized of the nSMases. nSMase 2 is localized to the inner leaflet of the plasma membrane, which is thought to be the major site for sphingomyelin hydrolysis (Marchesini, Jones et al. 2007, Tani and Hannun 2007, Milhas, Clarke et al. 2010). nSMase2 is also localized to a lesser extent to the Golgi, and recycling between the two sites has been shown to be important for the regulation of its enzymatic activity (Milhas, Clarke et al. 2010). nSMase2 activity and localization are dependent on binding of $\mathrm{Mg}^{2+}$ ions and the anionic phospholipid phosphatidylserine (PS) (Hofmann, Tomiuk et al. 2000, Wu, Clarke et al. 2011). nSMase2 has been implicated with a wide variety of biological functions and pathologies, including bone mineralization and skeletal development, lung disease, tumorigenesis, and the inflammatory response (Clarke, Truong et al. 2007, Kim, Okimoto et al. 2008, Goldkorn and Filosto 2010, Filosto, Castillo et al. 2011, Khavandgar, Poirier et al. 2011). Of particular interest in this discussion is the role of nSMase2 activation in driving apoptosis as part of the DDR; this will be addressed in detail in the following section. 
Acid sphingomyelinase: ASMase, encoded by gene SMPD1, is characterized by its activity at an acidic optimum pH (Jenkins, Canals et al. 2009). It is a soluble, highly disulfidebonded structure, which is either localized to the lysosome or secreted (Schissel, Schuchman et al. 1996). ASMase was identified to be lacking in patients suffering from Neimann-Pick's disease (NPD) (Schuchman 2007), a lysosomal storage disease in which sphingomyelin accumulates in the lysosome. Of particular interest with respect to the DDR, cells from NPD patients are resistant to apoptosis induced by ionizing radiation (Vit and Rosselli 2003). Hence the study of cells and tissues derived from NPD patients has greatly assisted in our current understanding of the roles and functions of ASMase in the DDR. Endothelial secretion of ASMase and increased ASMase activity plays a role in the early stages of atherosclerosis, diabetes, and chronic heart failure (Tabas 1999, Gorska, Baranczuk et al. 2003, Doehner, Bunck et al. 2007). ASMase activity has also been linked to depression, dementia, and cancer, amongst other (Smith and Schuchman 2008, Schuchman 2010)

Alkaline sphingomyelinase: Alk-SMases are the least-studied of all SMases. They are almost exclusively expressed in intestinal mucosa and liver tissue (Duan 2006) and appear to function in the digestion of dietary sphingomyelin (Zhang, Cheng et al. 2011). Alk-SMases are structurally unrelated to other SMases; in fact, they are classified as part of the family of nucleotide pyrophosphate/phosphodiesterases (NPPs) (Duan, Bergman et al. 2003)

Ceramide Synthases-Ceramide synthases (CerS) catalyze the de novo synthesis of ceramide through the condensation of a sphingoid base and a fatty acyl-coA (Sribney 1966). There are six human CerS proteins, CerS1-6, which differ in their defined utilization of acyl-chain lengths, such that each CerS preferentially generates a specific subset of ceramide chain-lengths (Mizutani, Kihara et al. 2005, Stiban, Tidhar et al. 2010). CerS are small, multi-pass transmembrane proteins located in the ER membrane (Mandon, Ehses et al. 1992, Hirschberg, Rodger et al. 1993). CerS6 has been predicted to possess five transmembrane domains, with a luminal N-terminus and cytosolic C-terminus (Mizutani, Kihara et al. 2005). The other CerS proteins are predicted to display similar topology due to their homology. CerS proteins have repeatedly been proven to play a significant role in the induction of apoptosis through the DDR (described in detail later in this review).

Ceramide in the DDR-Ceramide was first linked to the cellular apoptotic mechanism in the early 1990s, when several studies identified ceramide elevation and sphingomyelinase activation as key mediators in the apoptotic response to TNFa, Fas and ionizing radiation (Obeid, Linardic et al. 1993, Cifone, De Maria et al. 1994, Haimovitz-Friedman, Kan et al. 1994, Jarvis, Fornari et al. 1994). It is becoming increasingly clear that the mechanism of this ceramide-mediated apoptotic response is, at least in part, due to the ability of ceramide to trigger or hijack the cellular DNA damage response. In a similar fashion, ceramide is also able to induce cell cycle arrest through DDR elements. The following discussion presents our current understanding of the network surrounding ceramide as a secondary messenger, mediating the DDR to result in apoptosis or cell cycle arrest.

Sphingomyelin catabolism versus ceramide synthesis: Initially there was debate as to the source of ceramide elevation in the DDR: SMase activity or CerS activity. Membrane 
preparations devoid of nuclei exhibit ceramide elevation in response to ionizing radiation, via a rapid activation of nSMases (Haimovitz-Friedman, Kan et al. 1994). nSMases were also implicated in ceramide elevation in leukemia cell lines in response to the chemotherapeutic drug daunorubicin (Jaffrezou, Levade et al. 1996). In this study, two sphingomyelin hydrolysis cycles were observed, causing an increase in ceramide production. These cycles were accompanied by nSMase activation and were unaffected by treatment with CerS inhibitor fumonisin (FB1). ASMase has also been implicated in the ceramide-mediated apoptotic mechanism. Lymphoblasts from patients suffering from Nieman-Pick's disease (NPD) do not experience an elevation in ceramide production in response to irradiation, and are subsequently unable to undergo apoptosis (Santana, Pena et al. 1996). This effect is surmounted by retroviral insertion of human ASMase cDNA, indicating that ASMase is responsible for ceramide accumulation leading to apoptosis.

Bose et al., (Bose, Verheij et al. 1995) first proposed the alternative CerS-mediated mechanism for induction of apoptosis. Treatment of human and mouse leukemia cell lines with daunorubicin causes ceramide elevation due to activation of ceramide synthesis by ceramide synthases. Pre-incubation of cells with FB1 ablated this ceramide elevation and the apoptotic response, confirming the role of CerS in this mechanism. CerS was also reported to be activated in response to irradiation of endothelial cell lines, generating ceramide and inducing apoptosis (Liao, Haimovitz-Friedman et al. 1999).

These differences in observations were reconciled when ceramide generation was shown to be biphasic in nature in human lymphoblasts; ASMase activity causes a peak in ceramide within minutes following irradiation, whereas CerS activity increases ceramide levels several hours later (Vit and Rosselli 2003). The initial peak in ceramide is modest and transient, occurring with a corresponding decrease in sphingomyelin and an observed increase in ASMase activity. The later ceramide elevation is a more substantial increase occurring 8-24 hours post-irradiation. It is accompanied by an increase in CerS activity and is inhibited by pre-treatment with FB1. Interestingly, the second phase of ceramide elevation was observed to be dependent on the first, since it is absent in irradiated NPD lymphoblasts despite a normal increase in CerS activity. This implies that some product of sphingomyelin hydrolysis by ASMase is required for the second phase of ceramide generation. This split mode of ceramide generation appears to be characteristic of ceramide signaling in the DDR, and further study is needed to elucidate and thoroughly understand the differential activities of SMases and CerS and their downstream effects in the DDR.

Whilst overall CerS inhibition is known to protect cells from apoptosis, there are evidently some specific effects mediated by individual CerS proteins in the DDR. Overexpression of different CerS proteins in HEK-293 cells rendered them susceptible to different chemotherapeutic agents: CerS1 overexpression sensitizes cells to cisplatin, carboplatin, doxorubicin and vincristine; CerS5 overexpression sensitizes cells only to doxorubicin and vincristine; whereas overexpression of CerS4 sensitizes cells to none of the above (Min, Mesika et al. 2007). Whilst the general role of CerS in apoptosis makes them of interest as targets for chemotherapeutics or radiation sensitization, the observed differential signaling of different CerS proteins offers promise for more specific therapeutic targeting. However, 
there is currently little understanding about the differential actions of CerS proteins, and this is one area that requires further work before therapeutic intervention can be pursued.

Ceramide and p53: Dbaibo et al., (Dbaibo, Pushkareva et al. 1998) probed the involvement of 553 in ceramide-mediated induction of apoptosis, based on similarities in biological functions of p53 and ceramide. Actinomycin D and irradiation were used to induce apoptosis in Molt4 lymphocyte leukemia cells. Ceramide accumulation was observed to be p53-dependent, since p53 upregulation precedes ceramide elevation, and E6-mediated inhibition of $\mathrm{p} 53$ prevents accumulation of ceramide.

p53 is characteristically activated by ATM in the DNA damage response. A-T (ataxiatelangiectasia) cells possessing mutant ATM do not undergo apoptosis in response to irradiation, consistent with evidence that ceramide accumulation is p53-dependent. The first ASMase-dependent phase of ceramide elevation is observed as normal in A-T cells, whereas the second phase is absent and CerS activity is reduced (Vit and Rosselli 2003). These results indicate that the ASMase-mediated ceramide peak is ATM-independent, whereas CerS activation for the second phase is mediated by ATM and possibly, by extrapolation, p53.

Topoisomerase II inhibitor etoposide causes apoptosis in human glioma cells in a p53dependent manner. Activation of p53 and subsequent apoptosis were shown to be accompanied by an elevation in ceramide and activation of nSMase2, but not ASMase (Sawada, Nakashima et al. 2001). This is consistent with previous reports of DNA damaging agents, such as daunorubicin, causing ceramide-mediated apoptosis through activation of nSMase2 (Jaffrezou, Levade et al. 1996). However, it is now interesting that evidence is building for a model in which CerS and nSMase2 activation in the DDR are mediated by p53 and ATM, whereas activation of ASMase is not. There is also evidence that nSMase3 serves a distinct purpose in the DDR compared to other SMases. DNA damaging agent Adriamycin has been shown to down-regulate expression of nSMase3 in human colon cancer cells, and it appears that this down-regulation is mediated by activated p53 (Corcoran, He et al. 2008).

Ceramide, caspase 3 and PARP: The role of caspase- 3 and PARP in ceramide-mediated apoptosis is controversial and complex. Ceramide has been identified as a necessary mediator required for caspase- 3 activation in response to irradiation. Inhibition of caspase- 3 does not affect ceramide levels, indicating that ceramide elevation is upstream from caspase- 3 activation in the DDR. Cleavage of PARP and activation of capsase- 3 is entirely absent in NPD lymphoblasts or wild-type lymphoblasts pre-treated with FB1, indicating their requirement for ceramide generation(Vit and Rosselli 2003). Ceramide elevation was also observed to precede capsase-3 activation and PARP cleavage in a human lung adenocarcinoma cell line (Ravid, Tsaba et al. 2003).

Human leukemia cells treated with the inducer of apoptosis sodium nitroprusside (SNP) demonstrate nSMase2 activation, ceramide generation, and downstream apoptosis. Caspase inhibition is seen to block nSMase 2 activation, preventing apoptosis (Takeda, Tashima et al. 1999). Furthermore, purified, recombinant caspase- 3 was observed to increase activity of 
nSMase2 in a cell-free system. Studies focusing on late-stage CerS-mediated ceramide accumulation in UV-induced apoptosis also indicate that there is a pool of ceramide downstream from caspase activation (Mullen, Jenkins et al. 2011). In this study, caspase inhibition was seen to block UV-induced apoptosis. Although total cellular ceramide levels were unaffected by caspase inhibition, medium long-chain ceramide species were seen to be reduced. Whilst this observation implicates medium long chain ceramide with a role in UVinduced apoptosis downstream from caspase activation, it also more broadly implicates specific chain-length ceramide species with particular roles within the DDR. Taken altogether, the literature indicates a possible feed-forward network between caspase- 3 and ceramide (possibly distinguishing between different chain lengths at different levels of the DDR), driving towards apoptosis in the DDR.

There is also evidence of a caspase-independent ceramide-mediated apoptotic mechanism in the DDR. Fas-resistant Hodgkin's disease-derived cells showed no activation of caspase-3 or cleavage of PARP in response to increased ceramide. Inhibition of caspase-1 or caspase-3, or treatment with a pan-caspase inhibitor did not prevent ceramide-induced apoptosis, indicating an alternative mechanism in this instance (Metkar, Anand et al. 2000).

Ceramide and cell cycle arrest: The role of ceramide in the cell cycle arrest pathways of the DDR is less well characterized and in need of further study for a thorough grasp on its complexities. It is well-known that DNA damage results in cell cycle arrest through a number of complex mechanisms (Dasika, Lin et al. 1999). Evidence is gradually emerging that poses ceramide as a key mediator in this DDR pathway. Ceramide elevation results in cell cycle arrest at the G0/G1 phase. This effect is abrogated in the absence of retinoblastoma protein $(\mathrm{Rb})$ in MOLT4 cells, indicating that $\mathrm{Rb}$ acts as a mediator in ceramide-induced cell cycle arrest (Dbaibo, Pushkareva et al. 1995, Jayadev, Liu et al. 1995). Ceramide accumulation has also been shown to cause cell cycle arrest at the G2 phase, through induction of p21 (Phillips, Hunt et al. 2007). ATM and p53 are established as mediators of cell cycle arrest in the DDR (Kastan, Zhan et al. 1992). Since ceramide elevation has been shown to be a consequence of ATM and p53 activation (see previous section), it may be that ceramide acts a downstream effector for ATM/p53, at least in some instances.

NPD lymphoblasts experience normal induction of p53 and p21 - changes in which are important for induction of cell cycle arrest. Hence, irradiation-induced cell cycle arrest is not dependent on ASMase activity (Vit and Rosselli 2003), making it likely that this response is mediated either by CerS or nSMase2. Specific studies are needed to establish explicitly the dependence of DDR-induced cell cycle arrest on CerS and nSMase2 activity.

The mechanism of ceramide-induced cell cycle arrest is distinct from the apoptotic pathway, although both occupy branches of the DDR. Whereas ceramide-mediated apoptosis can be blocked by regulator of cell death bcl-2 (Ravid, Tsaba et al. 2003), cell cycle arrest resulting from ceramide-induced Rb activation is not bcl-2 dependent (Zhang, Alter et al. 1996, Phillips, Hunt et al. 2007). Overall, multiple modes of action within the DNA damage response have been identified for ceramide, sometimes with interdependent cross talk between them. The future of ceramide research in DDR will undoubtedly elucidate the 
complex network therein, particularly with respect to specificities in target and pathway switching.

\section{B. The Catabolism of Ceramide}

Ceramidases-Ceramidases (CDases) comprise a heterogeneous family of enzymes that function to catalyze the deacylation of ceramide, thereby releasing a free fatty acid of differing chain length depending on the ceramide species to form the 18-carbon amino alcohol sphingosine. CDases are currently classified into three categories (acid, neutral and alkaline) based on their optimal $\mathrm{pH}$ and primary structure. To date, five human CDases encoded by five distinct genes have been cloned, including acid ceramidase (AC), alkaline ceramidase (for which there are three alkaline ceramidase (ACER1), alkaline ceramidase 2 (ACER2), and alkaline ceramidase 3 (ACER3)), and neutral ceramidase (NC). Below we will discuss acid and neutral ceramidase, how they are regulated in response to DNA damage, and the role they play in the DDR through mediating ceramides and sphingosine.

Acid Ceramidase: Acid ceramidase (AC), a member of the N-terminal nucleophile (Ntn) hydrolase superfamily, is a lysosomal enzyme encoded by the $A S A H 1$ gene. During maturation, $\mathrm{AC}$ undergoes cysteine-dependent auto-proteolysis of a 50kDa polypeptide forming the mature heterodimeric enzyme that consists of two subunits, a (13kDa) and $\beta$ (40kDa). This maturation process is accelerated at acidic $\mathrm{pH}$, presumably to prevent premature maturation before entering the lysosomal compartment (Lansmann, Ferlinz et al. 1996). In addition to a preference for acidic $\mathrm{pH}(\sim 5), \mathrm{AC}$ also shows increased activity towards medium and long chain ceramides (C12 and C14) over short and very long chain ceramides, and also prefers unsaturated over saturated ceramides as substrates (Momoi, BenYoseph et al. 1982).

The physiological importance of AC is highlighted by the role it plays in the lysosomal storage disorder Farber's disease, which is characterized by a mutation in the AC gene leading to a deficiency in its activity and subsequent accumulation of lysosomal ceramide (Jameson, Holt et al. 1987). This disease thus provides a powerful tool to investigate AC and consequently many researchers have used different cell types from patients with Farber's Disease in order to elucidate the role AC plays in a number of biological processes, including the DDR. For example, both lymphocytes and fibroblasts from Farber's Disease patients were shown to be equally as sensitive to a number of stress stimuli and DNA damaging agents, demonstrating similar caspase activation compared to normal control cells. (Burek, Roth et al. 2001) (Segui, Bezombes et al. 2000).

In contrast, numerous studies have provided strong evidence that manipulations of AC, both genetically and pharmacologically, can have significant effects on cell fate in response to DNA damage. Several studies have demonstrated that AC is upregulated in approximately $60 \%$ of primary prostate cancer tissues (Seelan, Qian et al. 2000, Norris, Bielawska et al. 2006). In order to investigate the biological consequence of this overexpression, Saad et. al. generated human prostate cancer cells stably overexpressing AC and found that these cells were resistant to cell death induced by doxorubicin, cisplatin, etoposide, gemcitabine or C6 ceramide. Conversely, these AC-overexpressing cells could be sensitized to these DNA 
damaging agents following knock down of AC using siRNA (Saad, Meacham et al. 2007). In addition, Hara et. al. reported that AC protein expression in human U-87 glioblastoma cells was increased in a p53-dependent manner in response to $\gamma$-radiation and that inhibition of AC activity resulted in significant accumulation of ceramide and increased apoptosis in response to $\gamma$-radiation (Hara, Nakashima et al. 2004). Similarly, an elegant study by Cheng et. al demonstrated in prostate cancer cells that ceramide produced in response to radiation therapy, resulted in c-Jun/activator protein 1 mediated upregulation of AC at the mRNA level with subsequent increases in protein and enzyme activity level. This study identified a novel feedback system in cancer cells, where DNA damage-induced ceramide accumulation leads to induction of $\mathrm{AC}$ ultimately to reverse the proapoptotic effects of this ceramide accumulation. They subsequently demonstrated that interference with AC induction and activity resulted in significant ceramide accumulation and radiosensitization of cancer cells (Cheng, Bai et al. 2013). These observations, along with several other studies reviewed more extensively by Mao et. al. (Mao and Obeid 2008), suggest that the regulation of AC by DNA damaging agents can greatly impact cell fate.

Neutral Ceramidase: Neutral ceramidase (NC), encoded by the ASAH2 gene, is synthesized as a type II integral membrane protein via the secretory pathway. The $\mathrm{N}$ terminal cleavage of $\mathrm{NC}$ produces a soluble protein that can peripherally associate with the outer leaflet of the plasma membrane. NC also contains mucin box domains, allowing for a high level of O-glycosylation that is necessary for its association with the plasma membrane (Tani, Iida et al. 2003). NC is most active at neutral pH, as its name would suggest, and prefers long chain ceramides to medium chain as substrates (El Bawab, Roddy et al. 2000).

$\mathrm{NC}$ is expressed in diverse cellular locations. In particular the enzyme has been shown at very high levels in the intestinal epithelium and consequently its role in the digestion of dietary sphingolipids has been intensely studied. In vivo studies in the ASAH2-/- mice revealed that these mice were deficient in the ability to degrade dietary ceramides, although no other obvious abnormalities or major alterations in total ceramide levels in tissues were observed. As ceramide is a constituent in the diet of animals including humans, the enzymatic activity of NC in the intestines represents a homeostatic mechanism for maintaining cellular integrity and physiological function by preventing the inadvertent initiation of apoptosis by dietary ceramides (Kono, Dreier et al. 2006, Ohlsson, Palmberg et al. 2007).

Although a role of $\mathrm{NC}$ in intestinal tissues and digestion, is emerging, how this enzyme is regulated by the DDR is still under investigation. To this end, Wu et. al. demonstrated that treatment of polyoma middle $\mathrm{T}$ transformed murine endothelial cells with the chemotherapeutic agent Gemcitabine (GMZ) resulted in a selective reduction in NC protein level and enzyme activity, concomitant with increased levels of very long chain ceramides. The authors went on to show that GMZ treatment resulted in cell cycle arrest at the G0/G1 phase accompanied by dephosphorylation of the retinoblastoma protein $(\mathrm{Rb})$ and that these effects of GMZ on cell cycle arrest and ceramide accumulation could be recapitulated by siRNA knockdown of NC (Wu, Zeidan et al. 2009). Another study by Huwiler et. al. established a role for $\mathrm{NC}$ in apoptosis of rat renal mesangial cells in response to nitric oxide (NO). In this study the authors demonstrate that chronic exposure of renal mesangial cells to 
compounds releasing NO resulted in a decrease in ceramidase activity concomitant with increased sphingomyelinase activity, and significant increases in ceramide (Huwiler, Pfeilschifter et al. 1999). This group went on to demonstrate that NO induces NC degradation through the ubiquitin/proteasome complex, and that this proteasomal degradation is inhibited by direct phosphorylation of $\mathrm{NC}$ by protein kinase $\mathrm{C}$ (PKC) (Franzen, Fabbro et al. 2002, Franzen, Pfeilschifter et al. 2002).

Many more studies are needed in order to fully elucidate the role of NC in the DDR, as is the case with the alkaline ceramidases as there are currently no studies published on this topic. As the activity of these enzymes is responsible for the catabolism of ceramide, a key mediator of cell death, understanding how these enzymes are regulated in response to DNA damage is of great importance and could have significant implications in the identification of novel therapeutic targets.

\section{The Generation and breakdown of Sphingosine 1-Phosphate}

Sphingosine 1-Phosphate and the DDR-S1P is a potent bioactive lipid that plays roles in cell proliferation, angiogenesis and inflammation in addition to other functions (Hannun and Obeid 2008) (Pettus, Bielawski et al. 2003) (Pyne, Ohotski et al. 2014) (Nagahashi, Hait et al. 2014). S1P provokes these responses in cells by either acting directly on intracellular targets or through activation of a family of S1P-specific G-protein coupled receptors, S1P receptors 1-5 (van Koppen, Meyer zu Heringdorf et al. 1996). There are several enzymes responsible for the synthesis and breakdown of S1P and many studies have shown that in response to DNA damage these enzymes are differentially regulated in order to control S1P levels. The regulation of these enzymes by the DDR will be discussed in detail below.

Sphingosine Kinases-The Sphingosine kinases, consisting of Sphingosine kinase 1 (SK1) and 2 (SK2) are a group of lipid kinases that utilize ATP to catalyze the phosphorylation of the $\mathrm{C}-1$ hydroxy group of free sphingosine, producing the bioactive lipid product Sphingosine 1-Phosphate (S1P). The action of these two enzymes constitutes the only means for the production of S1P in the cell and therefore SK's hold a crucial position in sphingolipid metabolism: regulating the balance of prosurvival and proapoptotic signaling lipids (Pitson 2011, Siow, Anderson et al. 2011). Subsequently, alterations in these enzymes' activity in response to different stimuli, specifically in the context of DNA damage, could have major implications on cell fate.

Sphingosine Kinase 1: SK1, the most studied of the two SK isoforms, is predominantly a cytosolic enzyme that is known to translocate to the plasma membrane in response to activation of protein kinase C (PKC) and/or phospholipase D (PLD) or upon phosphorylation by ERK, move into the nucleus and even get secreted from endothelial cells (Ancellin, Colmont et al. 2002, Johnson, Becker et al. 2002, Inagaki, Li et al. 2003, Pitson, Moretti et al. 2003, Delon, Manifava et al. 2004). Many studies have shown that overexpression of SK1 occurs in many cancers and this overexpression correlates with advancement of disease progression, resistance to chemotherapeutic drugs and an overall 
poor prognosis (Johnson, Johnson et al. 2005, Kawamori, Osta et al. 2006, Shida, Takabe et al. 2008, Rosa, Marciano et al. 2013).

Over the past decade, the regulation of SK1 in response to DNA damage has been intensely studied, and the mechanisms of its regulation downstream of the DDR are now being elucidated. Work by Taha et. al. established a connection between the tumor suppressor p53 and SK1, whereby treatment of Molt-4 leukemia cells with a number of chemotherapeutics, including actinomycin $\mathrm{D}$ (act D), doxorubicin, etoposide, and $\gamma$-radiation resulted in a reduction in SK1 protein levels while mRNA levels remain unchanged, and that this reduction of SK1 protein was concomitant with p53 accumulation. This work also established that p53 was required for SK1 degradation through the use of a Molt-4 cell system expressing either the retroviral empty vector LXSN or the vector into which the E6 gene of human papilloma virus was inserted (Taha, Osta et al. 2004). The E6 protein has been shown to target p53 to ubiquitination and subsequent proteasomal degradation (Kessis, Slebos et al. 1993, Dbaibo, Pushkareva et al. 1998). Treatment of the vector control cells with act D resulted in a significant decrease in SK1 protein level and an approximately 50\% decrease in enzymatic activity; in contrast, cells overexpressing E6 failed to show loss of SK1 protein or activity in response to act D. To define further the mechanism behind p53mediated SK1 degradation in response to act $\mathrm{D}$ a number of protease inhibitors were employed. Inhibition of caspases 3, 6, 7, and 9 only partially reversed act D-induced SK1 loss, whilst inhibition of cathepsin B, a lysosomal protease, produced a significant reversal of SK1 decline by Act D (Taha, Osta et al. 2004).

Similarly, work by Heffernan-Stroud et al demonstrated that ultraviolet radiation treatment of mouse embryonic fibroblasts (MEFs) wild type for p53 resulted in significant decreases in SK1 protein and enzymatic activity, and that this decrease was abrogated in MEFs null for $\mathrm{p} 53$. Moreover they showed that $\mathrm{p} 53$-mediated SK1 degradation could be rescued by pretreating wild type MEFs with a caspase -2 inhibitor, suggesting that $\mathrm{p} 53$, through its activation of caspase-2, negatively regulates SK1 in response to genotoxic stress (HeffernanStroud, Helke et al. 2012). To further define SK1 as key downstream target of p53 tumor suppressor activity, in vivo studies using p53 null mice were performed. These mice spontaneously develop thymic lymphoma and showed elevated SK1 levels and activity as well as increased S1P levels and decreased ceramide levels compared to wild type mice. Interestingly, deletion of SK1 in p53 null mice completely abrogated the formation of thymic lymphomas and increased the life span of these mice by approximately $30 \%$. The double knockout mice also displayed significant increases in ceramide and sphingosine concomitant with reduction in S1P levels (Heffernan-Stroud, Helke et al. 2012).

These studies provide strong evidence that SK1 is a key downstream target of p53 in response to DNA damage and the resulting loss of SK1 may be essential for p53-mediated initiation of apoptosis or cell senescence (Taha, Osta et al. 2004, Heffernan-Stroud, Helke et al. 2012). As p53 is most commonly mutated, not completely lost in human cancers, with more than 50\% of all human cancers harboring a mutation in p53 (Vogelstein, Lane et al. 2000, Soussi 2007, Soussi and Wiman 2007, Weisz, Oren et al. 2007), it will be of great interest to investigate the regulation of SK1 in response to DNA damage in the presence of mutant $\mathrm{p} 53$. To this end, our lab has begun to investigate how SK1 is regulated in response 
to DNA damage in mutant p53 breast cancer cells. These studies have revealed that MDAMB-231 mutant p53 breast cancer cells do not activate Caspase 2 and SK1 proteolysis does not occur in response to doxorubicin treatment. Interestingly, we found that inhibition of the cell cycle protein, Checkpoint Kinase 1 (CHK1) a known inhibitor of Caspase 2 activation (Sidi, Sanda et al. 2008, Ando, Kernan et al. 2012), results in loss of SK1 protein that bypasses p53 (unpublished). This work could have important clinical application as CHK1 inhibitors are currently in clinical trial (Thompson and Eastman 2013).

It is worth noting at this point that p53 mediates ceramide levels through activation/ expression of SMases and CerS, as described previously in this review. In addition, both in vitro and in vivo studies have demonstrated that loss of SK1 leads to decreases in cell and tissue S1P levels and increases in ceramide levels, therefore loss of SK1 downstream of the DDR is another mechanism to regulate ceramide levels in addition to regulation of CerS and SMase (Heffernan-Stroud, Helke et al. 2012). Given the universally-acknowledged importance of p53 as a tumor suppressor protein, it would be interesting to pursue and dissect the mechanisms by which p53 apparently connects the DDR and sphingolipid pathways at multiple points.

Sphingosine Kinase 2: Although they are members of the same lipid kinase family, SK2 differs from SK1 in many respects including sub-cellular localization, substrate specificity and biological function. Unlike SK1, SK2 is found predominantly in the nucleus or perinuclear region of the cell and displays broader substrate specificity with the ability to phosphorylate sphingosine as well as phytosphingosine and dihydrosphingosine (Liu, Sugiura et al. 2000, Igarashi, Okada et al. 2003). Most surprisingly, SK2 and SK1 seem to elicit opposing roles within the cell; while SK1 activity is well established to enhance survival and prevent apoptosis in response to DNA damage (Johnson, Johnson et al. 2005, Kawamori, Osta et al. 2006, Shida, Takabe et al. 2008, Rosa, Marciano et al. 2013), SK2 has been shown to augment the apoptotic response and even induce apoptosis through its overexpression (Maceyka, Sankala et al. 2005, Sankala, Hait et al. 2007).

To this effect, Sankala et. al. demonstrated that endogenous SK2 is important for p53independent induction of p21 expression in response to doxorubicin in MCF7 human breast cancer cells. The authors showed that down-regulation of SK2 with siRNA resulted in decreased basal and doxorubicin-induced p21 expression as well as decreased $\mathrm{G}_{2} / \mathrm{M}$ cell cycle arrest in p53-inactivated MCF7 cells (Sankala, Hait et al. 2007). Also of interest, increased SK2 localization to the endoplasmic reticulum in response to serum starvation was shown to promote apoptosis concomitant with increased cytosolic free calcium and transfer of calcium to the mitochondria in NIH 3T3 fibroblasts (Maceyka, Sankala et al. 2005).

These studies are just beginning to unravel the function of SK2 in mediating cell fate in response to stress and DNA damage and therefore more studies are needed to fully clarify the role of SK2 in the DDR.

Sphingosine 1-Phosphate Phosphatases and Lyase-A cell has several modes of regulating S1P levels via the action of a number of enzymes. First S1P can be dephosphorylated at the cell surface by a family of broad specificity lipid phosphate 
phosphatases (Pyne, Long et al. 2005) or more specifically at the ER by a family of S1P specific phosphatases, SPP1 and SPP2 (Mandala, Thornton et al. 1998, Mandala, Thornton et al. 2000, Ogawa, Kihara et al. 2003). The action of both of these families of phosphatases on S1P generates its substrate sphingosine that can then serve as the backbone to produce complex sphingolipids, ceramides or phosphorylated to reform S1P. Secondly, S1P can be irreversibly broken down into hexadecenal and phosphoethanolamine by S1P lyase (S1PL) at the ER and therefore this enzyme serves as the terminal enzyme of sphingolipid catabolism (Ikeda, Kihara et al. 2004).

Sphingosine 1-Phosphate Phosphatases: As mentioned above, SPP1 and SPP2 are S1P and ER specific phosphatases that have been shown to play a role in regulating the reintroduction of sphingoid bases into ceramide species at the ER (Le Stunff, Galve-Roperh et al. 2002, Le Stunff, Giussani et al. 2007); more specifically overexpression of SPP1 has been shown to result in an increase in ceramide accumulation suggesting that dephosphorylation of S1P is a rate limiting step in the salvage pathway (Mandala, Thornton et al. 1998, Mandala, Thornton et al. 2000, Le Stunff, Giussani et al. 2007). Interestingly, Johnson et al. found that siRNA knockdown of SPP1 protects MCF7 breast cancer cells from daunorubicin-induced DNA damage and cell death (Johnson, Johnson et al. 2003).Also of interest, Oskouian et al. found by quantitative real-time PCR that both SPP1 and SPP2 were significantly down-regulated in human colorectal cancer tissue samples compared to normal adjacent tissue (Oskouian, Sooriyakumaran et al. 2006).

Although these studies do not elucidate how the enzymatic activity of SPPases are regulated in response to DNA damage, one could imagine (as these enzymes can greatly effect the levels of S1P and ceramide within the cell) that they are tightly regulated and more studies are needed to reveal the mechanism of this regulation.

Sphingosine 1-Phosphate Lyase: SPL holds a pivotal position in sphingolipid metabolism, as it is the terminal enzyme. Due to the location of SPL at the ER membrane, with its catalytic site facing the cytosolic surface of the ER, it has access to cytosolically produced S1P and all sphingoid phosphate bases must reach the ER for their final degradation by SPL (Ikeda, Kihara et al. 2004).

An interesting study by Oskouian and colleagues, found that increased SPL expression and activity in response to the topoisomerase II inhibitor etoposide or by overexpression of the enzyme promotes apoptosis, as shown by increased caspase-3 activity, annexin- $\mathrm{V}$ binding, poly-ADP-ribose (PARP) cleavage and nuclear condensation in several human cell lines. The authors then went on to determine that SPL promotes apoptosis in response to DNA damage through a pathway involving p53 and the protease Caspase 2, as chemical inhibition of 553 transcription activity and caspase 2 activity by pifithrin- $\alpha$ and Z-VDVAD-FMK respectively resulted in abrogation of SPL-mediated apoptosis (Oskouian, Sooriyakumaran et al. 2006). This study begins to characterize SPL as a mediator in the physiological response to DNA damage. 


\section{Conclusion}

To date, there have been identified a number of points at which sphingolipid metabolizing enzymes affect and are affected by the DNA damage response pathway (summarized in Table 1). These findings position sphingolipids with a potentially prominent role in the overall mechanism by which cells elicit the appropriate response to DNA damaging agents. Further study within this field will undoubtedly shed more light on the complexities of connections between sphingolipid metabolism and the DNA damage response, thus opening up new avenues for therapeutic manipulation and clinical intervention.

\section{Acknowledgments}

This work was supported by Veterans Affairs Merit Award (LMO), NIH Grants GM062887 (LMO), and PO1 CA097132 (LMO) and NIH F31 CA186547-01 (BLC)

\section{References}

Ancellin N, Colmont C, Su J, Li Q, Mittereder N, Chae SS, Stefansson S, Liau G, Hla T. Extracellular export of sphingosine kinase-1 enzyme. Sphingosine 1-phosphate generation and the induction of angiogenic vascular maturation. J Biol Chem. 2002; 277(8):6667-6675. [PubMed: 11741921]

Ando K, Kernan JL, Liu PH, Sanda T, Logette E, Tschopp J, Look AT, Wang J, Bouchier-Hayes L, Sidi S. PIDD death-domain phosphorylation by ATM controls prodeath versus prosurvival PIDDosome signaling. Mol Cell. 2012; 47(5):681-693. [PubMed: 22854598]

Bose R, Verheij M, Haimovitz-Friedman A, Scotto K, Fuks Z, Kolesnick R. Ceramide synthase mediates daunorubicin-induced apoptosis: an alternative mechanism for generating death signals. Cell. 1995; 82(3):405-414. [PubMed: 7634330]

Bunz F, Dutriaux A, Lengauer C, Waldman T, Zhou S, Brown JP, Sedivy JM, Kinzler KW, Vogelstein B. Requirement for p53 and p21 to sustain G2 arrest after DNA damage. Science. 1998; 282(5393): 1497-1501. [PubMed: 9822382]

Burek C, Roth J, Koch HG, Harzer K, Los M, Schulze-Osthoff K. The role of ceramide in receptorand stress-induced apoptosis studied in acidic ceramidase-deficient Farber disease cells. Oncogene. 2001; 20(45):6493-6502. [PubMed: 11641773]

Chen Y, Poon RY. The multiple checkpoint functions of CHK1 and CHK2 in maintenance of genome stability. Front Biosci. 2008; 13:5016-5029. [PubMed: 18508566]

Cheng JC, Bai A, Beckham TH, Marrison ST, Yount CL, Young K, Lu P, Bartlett AM, Wu BX, Keane BJ, Armeson KE, Marshall DT, Keane TE, Smith MT, Jones EE, Drake RR Jr, Bielawska A, Norris JS, Liu X. Radiation-induced acid ceramidase confers prostate cancer resistance and tumor relapse. J Clin Invest. 2013; 123(10):4344-4358. [PubMed: 24091326]

Cifone MG, De Maria R, Roncaioli P, Rippo MR, Azuma M, Lanier LL, Santoni A, Testi R. Apoptotic signaling through CD95 (Fas/Apo-1) activates an acidic sphingomyelinase. J Exp Med. 1994; 180(4):1547-1552. [PubMed: 7523573]

Clarke CJ, Truong TG, Hannun YA. Role for neutral sphingomyelinase-2 in tumor necrosis factor alpha-stimulated expression of vascular cell adhesion molecule-1 (VCAM) and intercellular adhesion molecule-1 (ICAM) in lung epithelial cells: p38 MAPK is an upstream regulator of nSMase2. J Biol Chem. 2007; 282(2):1384-1396. [PubMed: 17085432]

Corcoran CA, He Q, Ponnusamy S, Ogretmen B, Huang Y, Sheikh MS. Neutral sphingomyelinase-3 is a DNA damage and nongenotoxic stress-regulated gene that is deregulated in human malignancies. Mol Cancer Res. 2008; 6(5):795-807. [PubMed: 18505924]

Czornak K, Chughtai S, Chrzanowska KH. Mystery of DNA repair: the role of the MRN complex and ATM kinase in DNA damage repair. J Appl Genet. 2008; 49(4):383-396. [PubMed: 19029686]

Dasika GK, Lin SC, Zhao S, Sung P, Tomkinson A, Lee EY. DNA damage-induced cell cycle checkpoints and DNA strand break repair in development and tumorigenesis. Oncogene. 1999; 18(55):7883-7899. [PubMed: 10630641] 
Dbaibo GS, Pushkareva MY, Jayadev S, Schwarz JK, Horowitz JM, Obeid LM, Hannun YA. Retinoblastoma gene product as a downstream target for a ceramide-dependent pathway of growth arrest. Proc Natl Acad Sci U S A. 1995; 92(5):1347-1351. [PubMed: 7877980]

Dbaibo GS, Pushkareva MY, Rachid RA, Alter N, Smyth MJ, Obeid LM, Hannun YA. p53-dependent ceramide response to genotoxic stress. J Clin Invest. 1998; 102(2):329-339. [PubMed: 9664074]

Delon C, Manifava M, Wood E, Thompson D, Krugmann S, Pyne S, Ktistakis NT. Sphingosine kinase 1 is an intracellular effector of phosphatidic acid. J Biol Chem. 2004; 279(43):44763-44774. [PubMed: 15310762]

Doehner W, Bunck AC, Rauchhaus M, von Haehling S, Brunkhorst FM, Cicoira M, Tschope C, Ponikowski P, Claus RA, Anker SD. Secretory sphingomyelinase is upregulated in chronic heart failure: a second messenger system of immune activation relates to body composition, muscular functional capacity, and peripheral blood flow. Eur Heart J. 2007; 28(7):821-828. [PubMed: 17353227]

Duan RD. Alkaline sphingomyelinase: an old enzyme with novel implications. Biochim Biophys Acta. 2006; 1761(3):281-291. [PubMed: 16631405]

Duan RD, Bergman T, Xu N, Wu J, Cheng Y, Duan J, Nelander S, Palmberg C, Nilsson A. Identification of human intestinal alkaline sphingomyelinase as a novel ecto-enzyme related to the nucleotide phosphodiesterase family. J Biol Chem. 2003; 278(40):38528-38536. [PubMed: 12885774]

El Bawab S, Roddy P, Qian T, Bielawska A, Lemasters JJ, Hannun YA. Molecular cloning and characterization of a human mitochondrial ceramidase. J Biol Chem. 2000; 275(28):21508-21513. [PubMed: 10781606]

Filosto S, Castillo S, Danielson A, Franzi L, Khan E, Kenyon N, Last J, Pinkerton K, Tuder R, Goldkorn T. Neutral sphingomyelinase 2: a novel target in cigarette smoke-induced apoptosis and lung injury. Am J Respir Cell Mol Biol. 2011; 44(3):350-360. [PubMed: 20448054]

Franzen R, Fabbro D, Aschrafi A, Pfeilschifter J, Huwiler A. Nitric oxide induces degradation of the neutral ceramidase in rat renal mesangial cells and is counterregulated by protein kinase $\mathrm{C}$. J Biol Chem. 2002; 277(48):46184-46190. [PubMed: 12359735]

Franzen R, Pfeilschifter J, Huwiler A. Nitric oxide induces neutral ceramidase degradation by the ubiquitin/proteasome complex in renal mesangial cell cultures. FEBS Lett. 2002; 532(3):441-444. [PubMed: 12482609]

Gault CR, Obeid LM. Still benched on its way to the bedside: sphingosine kinase 1 as an emerging target in cancer chemotherapy. Crit Rev Biochem Mol Biol. 2011; 46(4):342-351. [PubMed: 21787121]

Goldkorn S, Filosto T. Lung injury and cancer: Mechanistic insights into ceramide and EGFR signaling under cigarette smoke. Am J Respir Cell Mol Biol. 2010; 43(3):259-268. [PubMed: 20525802]

Gorska M, Baranczuk E, Dobrzyn A. Secretory Zn2+-dependent sphingomyelinase activity in the serum of patients with type 2 diabetes is elevated. Horm Metab Res. 2003; 35(8):506-507. [PubMed: 12953170]

Goto H, Izawa I, Li P, Inagaki M. Novel regulation of checkpoint kinase 1: Is checkpoint kinase 1 a good candidate for anti-cancer therapy? Cancer Sci. 2012; 103(7):1195-1200. [PubMed: 22435685]

Haimovitz-Friedman A, Kan CC, Ehleiter D, Persaud RS, McLoughlin M, Fuks Z, Kolesnick RN. Ionizing radiation acts on cellular membranes to generate ceramide and initiate apoptosis. J Exp Med. 1994; 180(2):525-535. [PubMed: 8046331]

Hannun YA, Luberto C, Argraves KM. Enzymes of sphingolipid metabolism: from modular to integrative signaling. Biochemistry. 2001; 40(16):4893-4903. [PubMed: 11305904]

Hannun YA, Obeid LM. Principles of bioactive lipid signalling: lessons from sphingolipids. Nat Rev Mol Cell Biol. 2008; 9(2):139-150. [PubMed: 18216770]

Hara S, Nakashima S, Kiyono T, Sawada M, Yoshimura S, Iwama T, Banno Y, Shinoda J, Sakai N. p53-Independent ceramide formation in human glioma cells during gamma-radiation-induced apoptosis. Cell Death Differ. 2004; 11(8):853-861. [PubMed: 15088070] 
Heffernan-Stroud LA, Helke KL, Jenkins RW, De Costa AM, Hannun YA, Obeid LM. Defining a role for sphingosine kinase 1 in p53-dependent tumors. Oncogene. 2012; 31(9):1166-1175. [PubMed: 21765468]

Hirschberg K, Rodger J, Futerman AH. The long-chain sphingoid base of sphingolipids is acylated at the cytosolic surface of the endoplasmic reticulum in rat liver. Biochem J. 1993; 290(Pt 3):751757. [PubMed: 8457204]

Hofmann K, Tomiuk S, Wolff G, Stoffel W. Cloning and characterization of the mammalian brainspecific, Mg2+-dependent neutral sphingomyelinase. Proc Natl Acad Sci U S A. 2000; 97(11): 5895-5900. [PubMed: 10823942]

Huwiler A, Pfeilschifter J, van den Bosch H. Nitric oxide donors induce stress signaling via ceramide formation in rat renal mesangial cells. J Biol Chem. 1999; 274(11):7190-7195. [PubMed: 10066779]

Igarashi N, Okada T, Hayashi S, Fujita T, Jahangeer S, Nakamura S. Sphingosine kinase 2 is a nuclear protein and inhibits DNA synthesis. J Biol Chem. 2003; 278(47):46832-46839. [PubMed: 12954646]

Ikeda M, Kihara A, Igarashi Y. Sphingosine-1-phosphate lyase SPL is an endoplasmic reticulumresident, integral membrane protein with the pyridoxal 5'-phosphate binding domain exposed to the cytosol. Biochem Biophys Res Commun. 2004; 325(1):338-343. [PubMed: 15522238]

Inagaki Y, Li PY, Wada A, Mitsutake S, Igarashi Y. Identification of functional nuclear export sequences in human sphingosine kinase 1. Biochem Biophys Res Commun. 2003; 311(1):168173. [PubMed: 14575709]

Jaffrezou JP, Levade T, Bettaieb A, Andrieu N, Bezombes C, Maestre N, Vermeersch S, Rousse A, Laurent G. Daunorubicin-induced apoptosis: triggering of ceramide generation through sphingomyelin hydrolysis. EMBO J. 1996; 15(10):2417-2424. [PubMed: 8665849]

Jameson RA, Holt PJ, Keen JH. Farber's disease (lysosomal acid ceramidase deficiency). Ann Rheum Dis. 1987; 46(7):559-561. [PubMed: 3662645]

Jarvis WD, Fornari FA Jr, Browning JL, Gewirtz DA, Kolesnick RN, Grant S. Attenuation of ceramide-induced apoptosis by diglyceride in human myeloid leukemia cells. J Biol Chem. 1994; 269(50):31685-31692. [PubMed: 7989341]

Jayadev S, Liu B, Bielawska AE, Lee JY, Nazaire F, Pushkareva M, Obeid LM, Hannun YA. Role for ceramide in cell cycle arrest. J Biol Chem. 1995; 270(5):2047-2052. [PubMed: 7836432]

Jenkins RW, Canals D, Hannun YA. Roles and regulation of secretory and lysosomal acid sphingomyelinase. Cell Signal. 2009; 21(6):836-846. [PubMed: 19385042]

Johnson KR, Becker KP, Facchinetti MM, Hannun YA, Obeid LM. PKC-dependent activation of sphingosine kinase 1 and translocation to the plasma membrane. Extracellular release of sphingosine-1-phosphate induced by phorbol 12-myristate 13-acetate (PMA). J Biol Chem. 2002; 277(38):35257-35262. [PubMed: 12124383]

Johnson KR, Johnson KY, Becker KP, Bielawski J, Mao C, Obeid LM. Role of human sphingosine-1phosphate phosphatase 1 in the regulation of intra- and extracellular sphingosine-1-phosphate levels and cell viability. J Biol Chem. 2003; 278(36):34541-34547. [PubMed: 12815058]

Johnson KR, Johnson KY, Crellin HG, Ogretmen B, Boylan AM, Harley RA, Obeid LM. Immunohistochemical distribution of sphingosine kinase 1 in normal and tumor lung tissue. $\mathrm{J}$ Histochem Cytochem. 2005; 53(9):1159-1166. [PubMed: 15923363]

Kastan MB, Onyekwere O, Sidransky D, Vogelstein B, Craig RW. Participation of p53 protein in the cellular response to DNA damage. Cancer Res. 1991; 51(23 Pt 1):6304-6311. [PubMed: 1933891]

Kastan MB, Zhan Q, el-Deiry WS, Carrier F, Jacks T, Walsh WV, Plunkett BS, Vogelstein B, Fornace AJ Jr. A mammalian cell cycle checkpoint pathway utilizing p53 and GADD45 is defective in ataxia-telangiectasia. Cell. 1992; 71(4):587-597. [PubMed: 1423616]

Kawamori T, Osta W, Johnson KR, Pettus BJ, Bielawski J, Tanaka T, Wargovich MJ, Reddy BS, Hannun YA, Obeid LM, Zhou D. Sphingosine kinase 1 is up-regulated in colon carcinogenesis. FASEB J. 2006; 20(2):386-388. [PubMed: 16319132]

Kaye FJ. RB and cyclin dependent kinase pathways: defining a distinction between RB and p16 loss in lung cancer. Oncogene. 2002; 21(45):6908-6914. [PubMed: 12362273] 
Kessis TD, Slebos RJ, Nelson WG, Kastan MB, Plunkett BS, Han SM, Lorincz AT, Hedrick L, Cho KR. Human papillomavirus 16 E6 expression disrupts the p53-mediated cellular response to DNA damage. Proc Natl Acad Sci U S A. 1993; 90(9):3988-3992. [PubMed: 8387205]

Khavandgar Z, Poirier C, Clarke CJ, Li J, Wang N, McKee MD, Hannun YA, Murshed M. A cellautonomous requirement for neutral sphingomyelinase 2 in bone mineralization. J Cell Biol. 2011; 194(2):277-289. [PubMed: 21788370]

Kim WJ, Okimoto RA, Purton LE, Goodwin M, Haserlat SM, Dayyani F, Sweetser DA, McClatchey AI, Bernard OA, Look AT, Bell DW, Scadden DT, Haber DA. Mutations in the neutral sphingomyelinase gene SMPD3 implicate the ceramide pathway in human leukemias. Blood. 2008; 111(9):4716-4722. [PubMed: 18299447]

Koch J, Gartner S, Li CM, Quintern LE, Bernardo K, Levran O, Schnabel D, Desnick RJ, Schuchman $\mathrm{EH}$, Sandhoff K. Molecular cloning and characterization of a full-length complementary DNA encoding human acid ceramidase. Identification Of the first molecular lesion causing Farber disease. J Biol Chem. 1996; 271(51):33110-33115. [PubMed: 8955159]

Kono M, Dreier JL, Ellis JM, Allende ML, Kalkofen DN, Sanders KM, Bielawski J, Bielawska A, Hannun YA, Proia RL. Neutral ceramidase encoded by the Asah2 gene is essential for the intestinal degradation of sphingolipids. J Biol Chem. 2006; 281(11):7324-7331. [PubMed: 16380386]

Lansmann S, Ferlinz K, Hurwitz R, Bartelsen O, Glombitza G, Sandhoff K. Purification of acid sphingomyelinase from human placenta: characterization and $\mathrm{N}$-terminal sequence. FEBS Lett. 1996; 399(3):227-231. [PubMed: 8985151]

Le Stunff H, Galve-Roperh I, Peterson C, Milstien S, Spiegel S. Sphingosine-1-phosphate phosphohydrolase in regulation of sphingolipid metabolism and apoptosis. J Cell Biol. 2002; 158(6):1039-1049. [PubMed: 12235122]

Le Stunff H, Giussani P, Maceyka M, Lepine S, Milstien S, Spiegel S. Recycling of sphingosine is regulated by the concerted actions of sphingosine-1-phosphate phosphohydrolase 1 and sphingosine kinase 2. J Biol Chem. 2007; 282(47):34372-34380. [PubMed: 17895250]

Liao WC, Haimovitz-Friedman A, Persaud RS, McLoughlin M, Ehleiter D, Zhang N, Gatei M, Lavin M, Kolesnick R, Fuks Z. Ataxia telangiectasia-mutated gene product inhibits DNA damageinduced apoptosis via ceramide synthase. J Biol Chem. 1999; 274(25):17908-17917. [PubMed: 10364237]

Liu H, Sugiura M, Nava VE, Edsall LC, Kono K, Poulton S, Milstien S, Kohama T, Spiegel S. Molecular cloning and functional characterization of a novel mammalian sphingosine kinase type 2 isoform. J Biol Chem. 2000; 275(26):19513-19520. [PubMed: 10751414]

Maceyka M, Sankala H, Hait NC, Le Stunff H, Liu H, Toman R, Collier C, Zhang M, Satin LS, Merrill AH Jr, Milstien S, Spiegel S. SphK1 and SphK2, sphingosine kinase isoenzymes with opposing functions in sphingolipid metabolism. J Biol Chem. 2005; 280(44):37118-37129. [PubMed: 16118219]

Mandala SM, Thornton R, Galve-Roperh I, Poulton S, Peterson C, Olivera A, Bergstrom J, Kurtz MB, Spiegel S. Molecular cloning and characterization of a lipid phosphohydrolase that degrades sphingosine-1-phosphate and induces cell death. Proc Natl Acad Sci U S A. 2000; 97(14):78597864. [PubMed: 10859351]

Mandala SM, Thornton R, Tu Z, Kurtz MB, Nickels J, Broach J, Menzeleev R, Spiegel S. Sphingoid base 1-phosphate phosphatase: a key regulator of sphingolipid metabolism and stress response. Proc Natl Acad Sci U S A. 1998; 95(1):150-155. [PubMed: 9419344]

Mandon EC, Ehses I, Rother J, van Echten G, Sandhoff K. Subcellular localization and membrane topology of serine palmitoyltransferase, 3-dehydrosphinganine reductase, and sphinganine Nacyltransferase in mouse liver. J Biol Chem. 1992; 267(16):11144-11148. [PubMed: 1317856]

Mao C, Obeid LM. Ceramidases: regulators of cellular responses mediated by ceramide, sphingosine, and sphingosine-1-phosphate. Biochim Biophys Acta. 2008; 1781(9):424-434. [PubMed: 18619555]

Marchesini N, Jones JA, Hannun YA. Confluence induced threonine41/serine45 phospho-beta-catenin dephosphorylation via ceramide-mediated activation of PP1cgamma. Biochim Biophys Acta. 2007; 1771(12):1418-1428. [PubMed: 17996206] 
Mathias S, Pena LA, Kolesnick RN. Signal transduction of stress via ceramide. Biochem J. 1998; 335(Pt 3):465-480. [PubMed: 9794783]

Metkar SS, Anand M, Manna PP, Naresh KN, Nadkarni JJ. Ceramide-induced apoptosis in fasresistant Hodgkin's disease cell lines is caspase independent. Exp Cell Res. 2000; 255(1):18-29. [PubMed: 10666330]

Milhas D, Clarke CJ, Hannun YA. Sphingomyelin metabolism at the plasma membrane: implications for bioactive sphingolipids. FEBS Lett. 2010; 584(9):1887-1894. [PubMed: 19857494]

Min J, Mesika A, Sivaguru M, Van Veldhoven PP, Alexander H, Futerman AH, Alexander S. (Dihydro)ceramide synthase 1 regulated sensitivity to cisplatin is associated with the activation of p38 mitogen-activated protein kinase and is abrogated by sphingosine kinase 1. Mol Cancer Res. 2007; 5(8):801-812. [PubMed: 17699106]

Mizutani Y, Kihara A, Igarashi Y. Mammalian Lass6 and its related family members regulate synthesis of specific ceramides. Biochem J. 2005; 390(Pt 1):263-271. [PubMed: 15823095]

Momoi T, Ben-Yoseph Y, Nadler HL. Substrate-specificities of acid and alkaline ceramidases in fibroblasts from patients with Farber disease and controls. Biochem J. 1982; 205(2):419-425. [PubMed: 6814427]

Mullen TD, Jenkins RW, Clarke CJ, Bielawski J, Hannun YA, Obeid LM. Ceramide synthasedependent ceramide generation and programmed cell death: involvement of salvage pathway in regulating postmitochondrial events. J Biol Chem. 2011; 286(18):15929-15942. [PubMed: 21388949]

Nagahashi M, Hait NC, Maceyka M, Avni D, Takabe K, Milstien S, Spiegel S. Sphingosine-1phosphate in chronic intestinal inflammation and cancer. Adv Biol Regul. 2014; 54:112-120. [PubMed: 24210073]

Norris JS, Bielawska A, Day T, El-Zawahri A, ElOjeimy S, Hannun Y, Holman D, Hyer M, Landon C, Lowe S, Dong JY, McKillop J, Norris K, Obeid L, Rubinchik S, Tavassoli M, Tomlinson S, Voelkel-Johnson C, Liu X. Combined therapeutic use of AdGFPFasL and small molecule inhibitors of ceramide metabolism in prostate and head and neck cancers: a status report. Cancer Gene Ther. 2006; 13(12):1045-1051. [PubMed: 16763610]

Obeid LM, Linardic CM, Karolak LA, Hannun YA. Programmed cell death induced by ceramide. Science. 1993; 259(5102):1769-1771. [PubMed: 8456305]

Ogawa C, Kihara A, Gokoh M, Igarashi Y. Identification and characterization of a novel human sphingosine-1-phosphate phosphohydrolase, hSPP2. J Biol Chem. 2003; 278(2):1268-1272. [PubMed: 12411432]

Ohlsson L, Palmberg C, Duan RD, Olsson M, Bergman T, Nilsson A. Purification and characterization of human intestinal neutral ceramidase. Biochimie. 2007; 89(8):950-960. [PubMed: 17475390]

Oskouian B, Sooriyakumaran P, Borowsky AD, Crans A, Dillard-Telm L, Tam YY, Bandhuvula P, Saba JD. Sphingosine-1-phosphate lyase potentiates apoptosis via p53- and p38-dependent pathways and is down-regulated in colon cancer. Proc Natl Acad Sci U S A. 2006; 103(46): 17384-17389. [PubMed: 17090686]

Pettus BJ, Bielawski J, Porcelli AM, Reames DL, Johnson KR, Morrow J, Chalfant CE, Obeid LM, Hannun YA. The sphingosine kinase 1/sphingosine-1-phosphate pathway mediates COX-2 induction and PGE2 production in response to TNF-alpha. FASEB J. 2003; 17(11):1411-1421. [PubMed: 12890694]

Phillips DC, Hunt JT, Moneypenny CG, Maclean KH, McKenzie PP, Harris LC, Houghton JA. Ceramide-induced G2 arrest in rhabdomyosarcoma (RMS) cells requires p21Cip1/Waf1 induction and is prevented by MDM2 overexpression. Cell Death Differ. 2007; 14(10):1780-1791. [PubMed: 17627285]

Pitson SM. Regulation of sphingosine kinase and sphingolipid signaling. Trends Biochem Sci. 2011; 36(2):97-107. [PubMed: 20870412]

Pitson SM, Moretti PA, Zebol JR, Lynn HE, Xia P, Vadas MA, Wattenberg BW. Activation of sphingosine kinase 1 by ERK1/2-mediated phosphorylation. EMBO J. 2003; 22(20):5491-5500. [PubMed: 14532121]

Polyak K, Xia Y, Zweier JL, Kinzler KW, Vogelstein B. A model for p53-induced apoptosis. Nature. 1997; 389(6648):300-305. [PubMed: 9305847] 
Pyne NJ, Ohotski J, Bittman R, Pyne S. The role of sphingosine 1-phosphate in inflammation and cancer. Adv Biol Regul. 2014; 54:121-129. [PubMed: 24070975]

Pyne S, Long JS, Ktistakis NT, Pyne NJ. Lipid phosphate phosphatases and lipid phosphate signalling. Biochem Soc Trans. 2005; 33(Pt 6):1370-1374. [PubMed: 16246121]

Ravid T, Tsaba A, Gee P, Rasooly R, Medina EA, Goldkorn T. Ceramide accumulation precedes caspase-3 activation during apoptosis of A549 human lung adenocarcinoma cells. Am J Physiol Lung Cell Mol Physiol. 2003; 284(6):L1082-L1092. [PubMed: 12576296]

Reynolds CP, Maurer BJ, Kolesnick RN. Ceramide synthesis and metabolism as a target for cancer therapy. Cancer Lett. 2004; 206(2):169-180. [PubMed: 15013522]

Rosa R, Marciano R, Malapelle U, Formisano L, Nappi L, D'Amato C, D'Amato V, Damiano V, Marfe G, Del Vecchio S, Zannetti A, Greco A, De Stefano A, Carlomagno C, Veneziani BM, Troncone G, De Placido S, Bianco R. Sphingosine kinase 1 overexpression contributes to cetuximab resistance in human colorectal cancer models. Clin Cancer Res. 2013; 19(1):138-147. [PubMed: 23166225]

Saad AF, Meacham WD, Bai A, Anelli V, Elojeimy S, Mahdy AE, Turner LS, Cheng J, Bielawska A, Bielawski J, Keane TE, Obeid LM, Hannun YA, Norris JS, Liu X. The functional effects of acid ceramidase overexpression in prostate cancer progression and resistance to chemotherapy. Cancer Biol Ther. 2007; 6(9):1455-1460. [PubMed: 17881906]

Sankala HM, Hait NC, Paugh SW, Shida D, Lepine S, Elmore LW, Dent P, Milstien S, Spiegel S. Involvement of sphingosine kinase 2 in p53-independent induction of p21 by the chemotherapeutic drug doxorubicin. Cancer Res. 2007; 67(21):10466-10474. [PubMed: 17974990]

Santana P, Pena LA, Haimovitz-Friedman A, Martin S, Green D, McLoughlin M, Cordon-Cardo C, Schuchman EH, Fuks Z, Kolesnick R. Acid sphingomyelinase-deficient human lymphoblasts and mice are defective in radiation-induced apoptosis. Cell. 1996; 86(2):189-199. [PubMed: 8706124]

Sawada M, Nakashima S, Kiyono T, Nakagawa M, Yamada J, Yamakawa H, Banno Y, Shinoda J, Nishimura Y, Nozawa Y, Sakai N. p53 regulates ceramide formation by neutral sphingomyelinase through reactive oxygen species in human glioma cells. Oncogene. 2001; 20(11):1368-1378. [PubMed: 11313880]

Schissel SL, Schuchman EH, Williams KJ, Tabas I. Zn2+-stimulated sphingomyelinase is secreted by many cell types and is a product of the acid sphingomyelinase gene. J Biol Chem. 1996; 271(31): 18431-18436. [PubMed: 8702487]

Schuchman EH. The pathogenesis and treatment of acid sphingomyelinase-deficient Niemann-Pick disease. J Inherit Metab Dis. 2007; 30(5):654-663. [PubMed: 17632693]

Schuchman EH. Acid sphingomyelinase, cell membranes and human disease: lessons from NiemannPick disease. FEBS Lett. 2010; 584(9):1895-1900. [PubMed: 19944693]

Seelan RS, Qian C, Yokomizo A, Bostwick DG, Smith DI, Liu W. Human acid ceramidase is overexpressed but not mutated in prostate cancer. Genes Chromosomes Cancer. 2000; 29(2):137146. [PubMed: 10959093]

Segui B, Bezombes C, Uro-Coste E, Medin JA, Andrieu-Abadie N, Auge N, Brouchet A, Laurent G, Salvayre R, Jaffrezou JP, Levade T. Stress-induced apoptosis is not mediated by endolysosomal ceramide. FASEB J. 2000; 14(1):36-47. [PubMed: 10627278]

Shida D, Takabe K, Kapitonov D, Milstien S, Spiegel S. Targeting SphK1 as a new strategy against cancer. Curr Drug Targets. 2008; 9(8):662-673. [PubMed: 18691013]

Sidi S, Sanda T, Kennedy RD, Hagen AT, Jette CA, Hoffmans R, Pascual J, Imamura S, Kishi S, Amatruda JF, Kanki JP, Green DR, D'Andrea AA, Look AT. Chk1 suppresses a caspase-2 apoptotic response to DNA damage that bypasses p53, Bcl-2, and caspase-3. Cell. 2008; 133(5): 864-877. [PubMed: 18510930]

Siow DL, Anderson CD, Berdyshev EV, Skobeleva A, Natarajan V, Pitson SM, Wattenberg BW. Sphingosine kinase localization in the control of sphingolipid metabolism. Adv Enzyme Regul. 2011; 51(1):229-244. [PubMed: 21075134]

Smith EL, Schuchman EH. Acid sphingomyelinase overexpression enhances the antineoplastic effects of irradiation in vitro and in vivo. Mol Ther. 2008; 16(9):1565-1571. [PubMed: 18628757]

Soussi T. p53 alterations in human cancer: more questions than answers. Oncogene. 2007; 26(15): 2145-2156. [PubMed: 17401423] 
Soussi KG, Wiman T. Shaping genetic alterations in human cancer: the p53 mutation paradigm. Cancer Cell. 2007; 12(4):303-312. [PubMed: 17936556]

Sribney M. Enzymatic synthesis of ceramide. Biochim Biophys Acta. 1966; 125(3):542-547. [PubMed: 5973195]

Stiban J, Tidhar R, Futerman AH. Ceramide synthases: roles in cell physiology and signaling. Adv Exp Med Biol. 2010; 688:60-71. [PubMed: 20919646]

Tabas I. Secretory sphingomyelinase. Chem Phys Lipids. 1999; 102(1-2):123-130. [PubMed: 11001566]

Taha TA, Osta W, Kozhaya L, Bielawski J, Johnson KR, Gillanders WE, Dbaibo GS, Hannun YA, Obeid LM. Down-regulation of sphingosine kinase-1 by DNA damage: dependence on proteases and p53. J Biol Chem. 2004; 279(19):20546-20554. [PubMed: 14988393]

Takeda Y, Tashima M, Takahashi A, Uchiyama T, Okazaki T. Ceramide generation in nitric oxideinduced apoptosis. Activation of magnesium-dependent neutral sphingomyelinase via caspase-3. J Biol Chem. 1999; 274(15):10654-10660. [PubMed: 10187863]

Tani YA, Hannun M. Analysis of membrane topology of neutral sphingomyelinase 2. FEBS Lett. 2007; 581(7):1323-1328. [PubMed: 17349629]

Tani M, Iida H, Ito M. O-glycosylation of mucin-like domain retains the neutral ceramidase on the plasma membranes as a type II integral membrane protein. J Biol Chem. 2003; 278(12):1052310530. [PubMed: 12499379]

Thompson A, Eastman R. The cancer therapeutic potential of Chk1 inhibitors: how mechanistic studies impact on clinical trial design. Br J Clin Pharmacol. 2013; 76(3):358-369. [PubMed: 23593991]

Upton JP, Austgen K, Nishino M, Coakley KM, Hagen A, Han D, Papa FR, Oakes SA. Caspase-2 cleavage of BID is a critical apoptotic signal downstream of endoplasmic reticulum stress. Mol Cell Biol. 2008; 28(12):3943-3951. [PubMed: 18426910]

van Koppen C, Meyer zu Heringdorf M, Laser KT, Zhang C, Jakobs KH, Bunemann M, Pott L. Activation of a high affinity Gi protein-coupled plasma membrane receptor by sphingosine-1phosphate. J Biol Chem. 1996; 271(4):2082-2087. [PubMed: 8567663]

Vit JP, Rosselli F. Role of the ceramide-signaling pathways in ionizing radiation-induced apoptosis. Oncogene. 2003; 22(54):8645-8652. [PubMed: 14647458]

Vogelstein B, Lane D, Levine AJ. Surfing the p53 network. Nature. 2000; 408(6810):307-310. [PubMed: 11099028]

Weisz L, Oren M, Rotter V. Transcription regulation by mutant p53. Oncogene. 2007; 26(15):22022211. [PubMed: 17401429]

Wu BX, Clarke CJ, Matmati N, Montefusco D, Bartke N, Hannun YA. Identification of novel anionic phospholipid binding domains in neutral sphingomyelinase 2 with selective binding preference. $\mathrm{J}$ Biol Chem. 2011; 286(25):22362-22371. [PubMed: 21550973]

Wu BX, Zeidan YH, Hannun YA. Downregulation of neutral ceramidase by gemcitabine: Implications for cell cycle regulation. Biochim Biophys Acta. 2009; 1791(8):730-739. [PubMed: 19345744]

Yin C, Knudson CM, Korsmeyer SJ, Van Dyke T. Bax suppresses tumorigenesis and stimulates apoptosis in vivo. Nature. 1997; 385(6617):637-640. [PubMed: 9024662]

Zhang J, Alter N, Reed JC, Borner C, Obeid LM, Hannun YA. Bcl-2 interrupts the ceramide-mediated pathway of cell death. Proc Natl Acad Sci U S A. 1996; 93(11):5325-5328. [PubMed: 8643573]

Zhang Y, Cheng Y, Hansen GH, Niels-Christiansen LL, Koentgen F, Ohlsson L, Nilsson A, Duan RD. Crucial role of alkaline sphingomyelinase in sphingomyelin digestion: a study on enzyme knockout mice. J Lipid Res. 2011; 52(4):771-781. [PubMed: 21177474] 


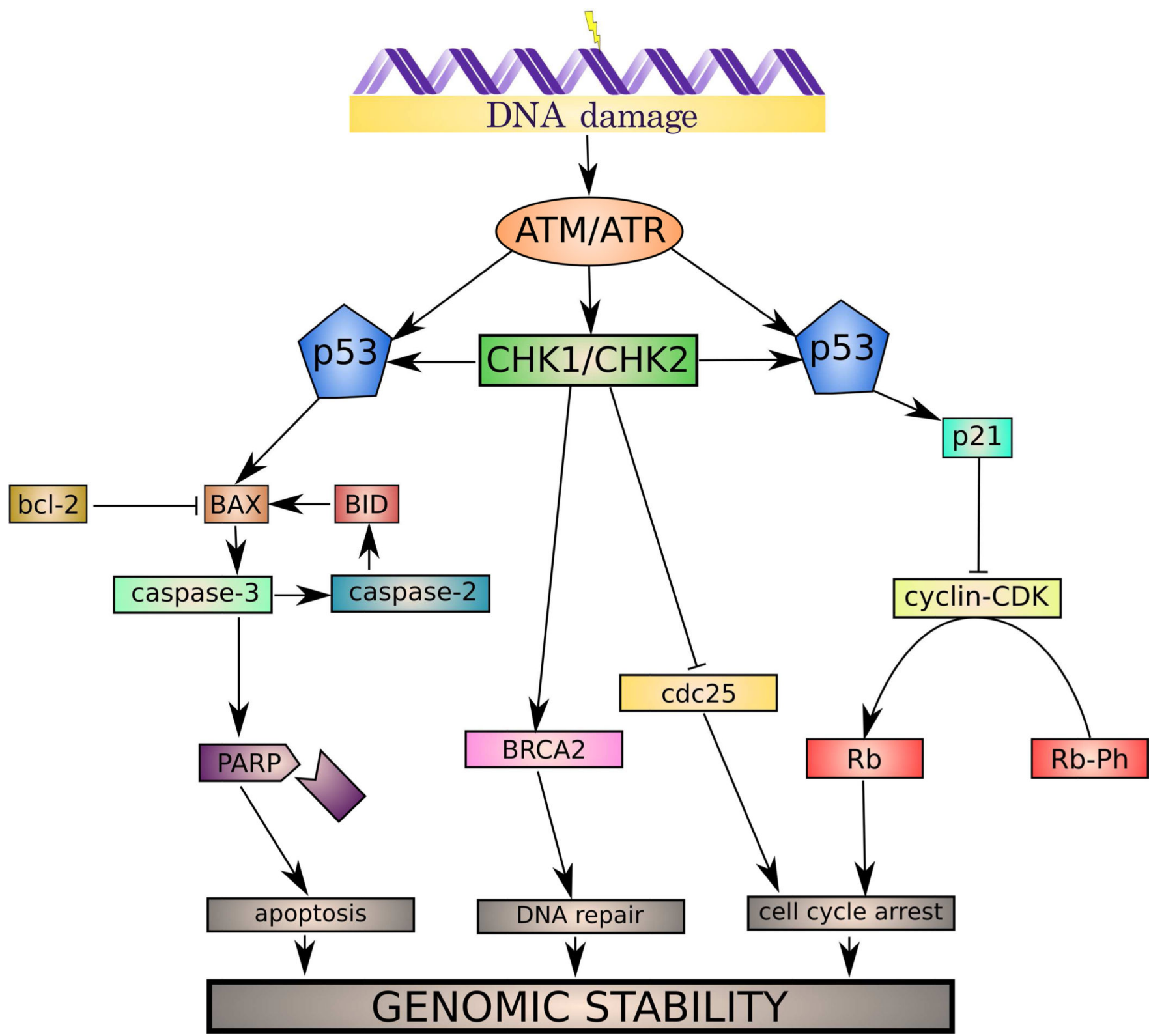

Figure 1.

Schematic of the fundamental aspects of the DNA damage response pathway. DNA damage triggers activation of ATM and ATR, which in turn activate p53, CHK1 and CHK2. Activated p53 signals an apoptotic pathway through BAX and caspase-3-mediated PARP cleavage. p53 also signals through p21, cyclin-CDK and RB protein to cause cell cycle arrest. CHK1 and CHK2 can signal through BRCA2 to trigger DNA repair, or through the inhibition of cdc25 to cause cell cycle arrest. CHK1 and CHK2 are also able to activate p53. All signaling events in the DNA damage response ultimately serve to increase genomic stability in the cell. 


\section{Table 1}

Summary of current knowledge o the interaction between components of the sphingolipid signaling pathway and the DNA damage response.

\begin{tabular}{|lllll|}
\hline $\begin{array}{c}\text { Sphingolipid signaling } \\
\text { component }\end{array}$ & $\begin{array}{l}\text { Effect of DNA damage } \\
\text { on activation/expression }\end{array}$ & $\begin{array}{l}\text { DDR components } \\
\text { shown to be upstream }\end{array}$ & $\begin{array}{l}\text { DDR components shown } \\
\text { to be downstream }\end{array}$ \\
\hline Ceramide & & $\uparrow$ & ATM, p53, p21, Caspase-3, bcl-2 & Caspase-3, PARP, p21, Rb \\
SMase & nSMase2 & $\uparrow$ & Caspase-3, ATM, p53 & \\
& nSMase3 & $\downarrow$ & p53 & \\
& ASMase & $\uparrow$ & & Caspase-3, PARP \\
CerS & & $\uparrow$ & ATM, ASMase, (bcl-2?) & Caspase-3, PARP, (bcl-2?) \\
CDase & AC & $\uparrow($ in cancer cells) & p53 & $?$ \\
& NC & $\downarrow$ & $?$ & Rb \\
SK & SK1 & $\downarrow$ & p53, Caspase 2, CHK1 & p21, p16 \\
& SK2 & $\uparrow$ & $?$ & p21 \\
SPP1 \& 2 & & $\downarrow$ & $?$ & $?$ \\
SPL & & $\downarrow$ & p53, Caspase 2 & \\
\hline
\end{tabular}

